\title{
Redaksjonelt
}

\section{Lim, hukommelse og sprengkraft}

Tidsskriftet Sakprosa

Bind 13, Nummer 3

(C) 2021 


\section{Lim, hukommelse og sprengkraft}

«Sakprosaen er samfunnets lim og hukommelse», erklærte jeg optimistisk i boka Hva er sakprosa i 2008. Men prosaen kan også oppløse limet og få oss til å miste hukommelsen. Sakprosaen er en kraft som setter i gang handlinger, minner Jack Andersen om i sin artikkel av året hvor han vil utvikle en samfunnsteori om sakprosa. Tekster har sprengkraft. Men som kjent kan sprengstoff både brukes til å bygge opp og bryte ned, slik vi nesten bokstavelig blir minnet om hvert år når dynamitt-fabrikanten Alfred Nobels fredspris deles ut.

Sakprosa kan bygge demokrati, men også få det til å forvitre. I de sosiale medienes barndom var det mange som så et nytt håp for demokratiet. Nå skulle demos komme skriftlig og offentlig til orde uten å være utsatt for sensurerende redaktører. Det gikk ikke lang tid før debatten gikk høyt om ordbruken i den nye flommen av ytringer. Skjellsord og sjikanerende uttrykk florerte, og «nett-trollene» krøp ut av sine berg. Men bortsett fra stygge ord og dårlig tone: Hvordan ble debatten? Ida Andersen konstaterer i sin artikkel i dette nummeret, på grunnlag av analyser av kommentarfelt på Facebook, at utveksling nå ofte er avløst av framvisning av meninger. De framviste meningene er basert på hva hun kaller «uttrykksprinsippet». I kommentarfeltene skal vi vise oss fram med våre egne autentiske følelser. Uttrykksprinsippet tilsier at når vi føler sterkt nok, er argumenter overflødige. Men argumenter og motargumenter binder debatt sammen. Hvis Andersens diagnose holder stikk, betyr det at prosaen løser limet opp. Kommentarfeltene er i så fall lite egnet til å bidra til den «åpne og opplyste samtalen» som den norske Grunnloven oppfordrer til i sin «ytringsfrihetsparagraf».

Deliberasjon er det som folkeforsamlingen driver med, ifølge den klassisk retoriske sjangerlæren. Her diskuteres det hva som bør gjøres. Skal vi tro Ida Andersen, må følelsesbasert lovtale og nidtale, såkalt epideiktisk tale, altså 
den neste av de klassiske sjangrene, være blitt SoMe's foretrukne sjanger. I den tredje sjangeren, den som praktiseres i rettsalen, er spørsmålet hva som skjedde og hvem som hadde skylden. Retten er altså en stor hukommelsesmaskin: Her skal ikke bare vitnene huske, men lag på lag av tidligere dommer, forskrifter og lovparagrafer danner et stort arkiv. Og når dommen skal falle, kan ytringer og tekster danne avgjørende bevis, i tillegg til lik, blodflekker og tjuvgods. Det er avgjørende både for demokrati og rettssikkerhet at bevisførselen går ordentlig for seg også når det gjelder språklige bevis og indisier. Slikt bevismateriale er av et annet slag enn DNA-prøver, men den språklige bevisførselen må være like ambisiøs som den biologiske. Den andre artikkelen i dette nummeret retter et sterkt kritisk blikk mot kvaliteten på rettssalens språklige bevisførsel, med utgangspunkt i en berømt norsk rettssak hvor justisministerens samboer mottok trusselbrev preget av språklige pussigheter. Lingvistene Guro Fløgstad og Urdland Karlsen argumenterer overbevisende for at «rettslingvistikk» bør utvikles til å bli et troverdig bidrag til rettspleien.

Selvsagt er det håp både for samfunnets lim og for vår felles hukommelse. Men ikke uten at vi argumenterer redelig og drar nytte av faglige innsikter i språkets sprengkraft.

Johan L. Tønnesson 